\title{
SOLID WASTE MANAGEMENT IN GREATER SHILLONG PLANNING AREA (GSPA) USING SPATIAL MULTI-CRITERIA DECISION ANALYSIS FOR SITE SUITABILITY ASSESSMENT
}

\author{
B. S. Mipun ${ }^{\text {a }}$, R. Hazarika ${ }^{\text {b }}$, M. Mondal ${ }^{\text {c }}$, Sovanlal Mukhopadhyay ${ }^{\text {c }}$ \\ a ,b,c,d North-Eastern Hill University, Department of Geography, Shillong, Meghalaya- India \\ absmipun@hotmail.com, ${ }^{\mathrm{b}}$ roopz.hazarika36@gmail.com, ${ }^{\mathrm{c}}$ mm.rsgis@gmail.com, ${ }^{\mathrm{c}}$ mj.sovan@gmail.com
}

KEY WORDS: solid waste, segregation, garbage, landfill, organic, MCDA, GSPA.

\begin{abstract}
:
In Shillong city the existing solid waste management system is mobile waste bins (72\%). About 12 percent burn the waste generated by them. Door to door collection is about 5 percent. Over 2 percent households throw the wastes in the open space. Another 9 percent households throw their wastes into the waste bins located in the neighbourhood. The local headman takes care about half of the household's wastes, while Municipality takes care about 34 percent households. About 10 percent households are ignorant about the collection and disposal of wastes. Some NGO's takes care about 5 percent household's wastes. Awareness about segregation of waste into organic and non-bio degradable waste is 64 percent and a significant numbers do the segregation. In Shillong Municipality Board (SMB) area collects 45.91\% (78.42 MT) waste, outside SMB area collection is $32.61 \%$ (45.99 MT) and entire GSPA the percentage of garbage collected is 41 percent. The only dumping ground in GSPA is Marten, Mawiong, and the capacity to hold garbage is decreasing due to limited landfill. The sanitary landfill site is 5.0 acres that it is not enough to meet the demand. Out of he total area $170.69 \mathrm{sq} . \mathrm{km}$. (GSPA) only $25.67 \%$ is most suitable and $18.58 \%$ is unsuitable to set up a new landfill area. Eastern part of the GSPA, is most suitable, which fulfils the entire criterion adopted in this study. In this the best-stated criterion are land cover (vacant space), slope $(<15 \%)$, proximity to road $(400-800 \mathrm{~m})$, distance from River $(>2000 \mathrm{~m})$ and elevation $(1300-1500 \mathrm{~m})$. The eastern part of the GSPA is most suitable landfill location.
\end{abstract}

\section{INTRODUCTION}

In India, the management of solid waste is integral part to city sanitation. Over the last decade, larger cities, especially those with financial and managerial capacity, have attempted to improve waste management practices in response to the Municipal Solid Waste (MSW) Rules 2000. In this, the development of disposal infrastructure, i.e., sanitary landfill has made the least progress due to factors ranging from land scarcity to lack of technical and financial capacity in cities. Recognising these challenges, the Government of India and key stakeholders have been deliberating upon mechanisms and arrangements to facilitate compliance with requirements for treatment and safe disposal of solid waste. Regional facilities may incorporate treatment as well as disposal facilities to enhance technical and financial efficiencies. This facilitates the monitoring of environmental outcomes and performances of sites.

Greater Shillong Planning Area with its total population of 312,539 (Census, 2011) accounts for $78 \%$ of the total urban population of Meghalaya. Distribution of population within GSPA is not consistent with Shillong Urban Agglomeration area, which is densely populated. Only $14 \%$ of the total geographical area of Greater Shillong i.e. the core area is supporting $82 \%$ of the total population. While the population growth rate in Shillong Municipality area and the Cantonment area have continuously declining, the urban centres within the SUA i.e., Pynthorumkhrah and Madantring (classified as urban in 1981) have shown high growth rates.
Table 1.1. Population of GSPA (census years)

\begin{tabular}{|l|r|r|r|r|r|r|}
\hline \multicolumn{1}{|c|}{ Wards } & $\begin{array}{c}\text { Area } \\
\text { (sq.km) }\end{array}$ & \multicolumn{1}{c|}{$\mathbf{1 9 7 1}$} & $\mathbf{1 9 8 1}$ & $\mathbf{1 9 9 1}$ & $\mathbf{2 0 0 1}$ & $\mathbf{2 0 1 1}$ \\
\hline Shillong Mcplty. & 10.25 & 87569 & 109244 & 131719 & 132867 & 142059 \\
\hline Shillong Cantt. & 1.84 & 4730 & 6520 & 11076 & 12396 & 15022 \\
\hline Nongthymmai & 2.93 & 16103 & 21558 & 26938 & 34292 & 41097 \\
\hline Mawlai & 6.14 & 14260 & 20405 & 30964 & 38303 & 48635 \\
\hline Madanriting & 2.02 & - & 6165 & 8987 & 16318 & 24369 \\
\hline Pythormkhrah & 2.11 & - & 10711 & 13682 & 22115 & 30011 \\
\hline Nongmynsong & 2 & 1828 & 2902 & 6087 & 11371 & 16602 \\
\hline Shillong UA & 27.29 & 124490 & 177505 & 229453 & 267662 & 315791 \\
\hline 32 villages & 143.35 & 32848 & 42571 & 47747 & 63711 & 75105 \\
\hline Total GSPA & 174.64 & 157338 & 220076 & 277200 & 331373 & 390896 \\
\hline
\end{tabular}

Data source: North Eastern Region Capital Cities Development Investment Programme.

In this investigation, main emphasis is on site suitability analysis of SWM in GSPA using GIS and MCDA method. Solid waste infrastructure in Shillong is inadequate for the growing population. There are too few collection points and people deposit their solid waste on open grounds where it creates unhealthy environment and health hazard. Although the municipality collects the waste from these areas periodically, the service is inadequate. This garbage's are collected and transported to existing landfill located in Marten. Due to population growth the amount of garbage also increasing and dumping landfills holding capacity is decreasing. From the existing Landuse/landcover area identifying a suitable landfill area is the objective of this study.

The solid waste generated in the GSPA is 159 metric ton per day with the rate at 400 gram per capita per day. The major solid waste generation sources are households $(56 \%)$, markets 
(23\%), hotels \& restaurants $(7 \%)$, construction waste $(2 \%)$, and street sweeping $(7 \%)$.

\section{OBJECTIVES}

The objectives of the study is -

i. To identify a suitable solid waste dumping sites other than existing site.

ii. To map the ideal location of landfill using MCDA

iii. To recommend modern Solid Waste Management System

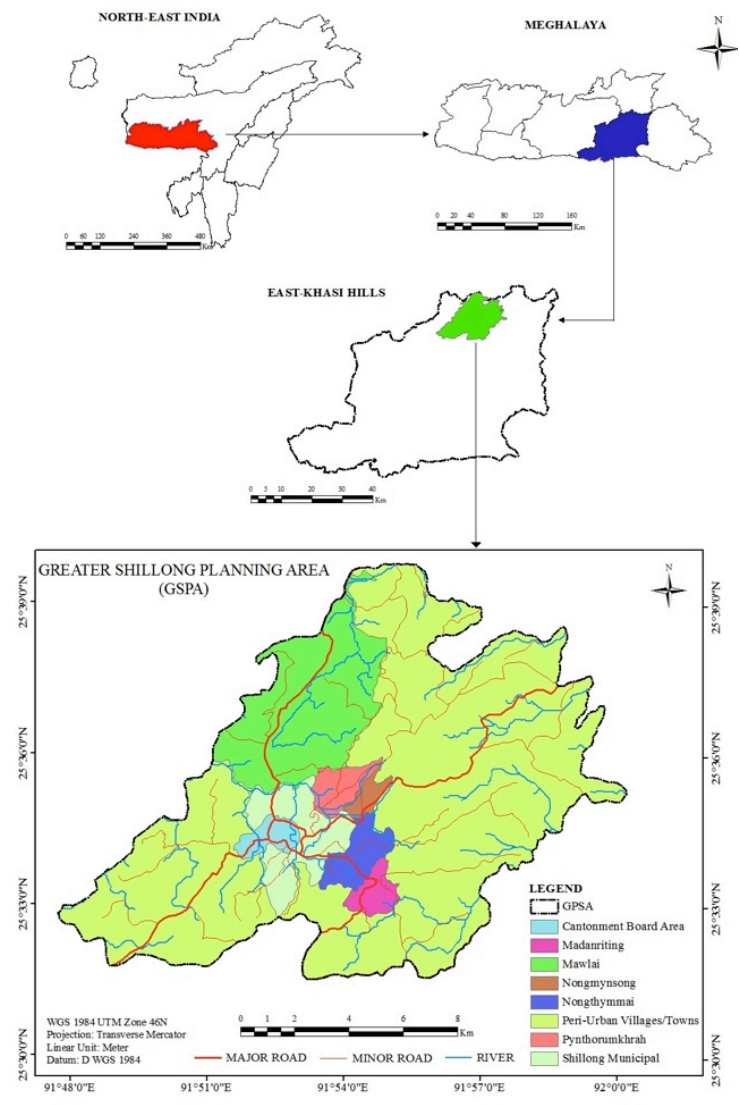

Figure 2.1. Location map of the study area (GSPA)

\section{DATA AND METHODOLOGY}

\subsection{Data}

Both primary and secondary data were used in this study. The primary data were collected from field survey and observation. The secondary data acquired from Internet, reports, books, journals, governmental institutions and other documents. The satellite data used for this study were LANDSAT and ASTER DEM of the town with spatial resolution of $30 \mathrm{~m}$., master plan of the town and topographical map of the town.

\subsection{Multi-Criteria Decision Analysis (MCDA)}

Multi Criteria Decision Analysis is a set of systematic procedures for analysing complex decision problems. These procedures include dividing the decision problems into smaller and more understandable; analysing; and integrating in a logical manner to produce a meaningful solution (Malczewski, 1997). In general, MCDA problems involve six components (Keeney and Raiffa, 1976; Pitz and McKillip, 1984):
- A goal or a set of goals the decision makers want to achieve,

- The decision maker or a group of decision makers involved in the decision making process with their preferences with respect to the evaluation criteria,

- A set of evaluation criteria (objectives and/or physical attributes)

- The set of decision alternatives,

- The set of uncontrollable (independent) variables or states of nature (decision environment),

The set of outcomes or consequences associated with each alternative attribute pair.

\subsubsection{Evaluation Criteria}

After the determination of the problem, the set of evaluation criteria, which includes attributes and objectives, should be designated (Keeney and Raiffa, 1976). This stage involves specifying a comprehensive set of objectives that reflects all concerns relevant to the decision problem and measures for achieving those objectives, which are defined as attributes. Because the evaluation criteria are related to geographical entities and the relationships between them can be represented in the form of maps, which are referred as attribute maps. GIS data handling and analysing capabilities are used to generate inputs to spatial decision making analysis (Malczewski, 1999).

\subsubsection{Ranking Method}

This is the simplest method for evaluating the importance of weights, which include every criterion under consideration, is ranked in order of decision maker's preferences. Due to its simplicity, the method is very attractive. However, the larger the number of criteria used, the less appropriate is the method. Another disadvantage is lack of theoretical foundation.

\subsubsection{Pairwise Comparison Method}

The method involves pairwise comparisons to create a ratio matrix. It takes pairwise comparisons as inputs and produce relative weights as output. The pairwise comparison method involves three steps.

Development of a pairwise comparison matrix: The method uses a scale with values range from 1 to 9 .

i. Computation of the weights: The computation of weights involves three steps. First step is the summation of the values in each column of the matrix. Then, each element in the matrix should be divided by its column total (the resulting matrix is referred to as the normalized pairwise comparison matrix). Then, computation of the average of the elements in each row of the normalized matrix should be made. This includes dividing the sum of normalized scores for each row by the number of criteria. These averages provide an estimate of the relative weights of the criteria being compared.

ii. Estimation of the consistency ratio: The aim of this is to determine if the comparisons are consistent or not. It involves following operations:

a. Determine the weighted sum vector by multiplying the weight for the first criterion times the first column of the original 
pairwise comparison matrix, then multiply the second weight times the second column, the third criterion times the third column of the original matrix, finally sum these values over the rows,

b. Determine the consistency vector by dividing the weighted sum vector by the criterion weights determined previously.

c. Compute lambda $(\lambda)$ which is the average value of the consistency vector and Consistency Index (CI) which provides a measure of departure from consistency and has the formula below:

$$
\mathrm{CI}=(\lambda-\mathrm{n}) /(\mathrm{n}-1)
$$

Calculation of the consistency ratio (CR), which is defined as follows:

$$
\mathrm{CR}=\mathrm{CI} / \mathrm{RI}
$$

Where RI is the random index and depends on the number of elements being compared. If CR is $<0.10$, the ratio indicates a reasonable level of consistency in the pairwise comparison, however, if $\mathrm{CR} \geq 0.10$, the values of the ratio indicates inconsistent judgments.

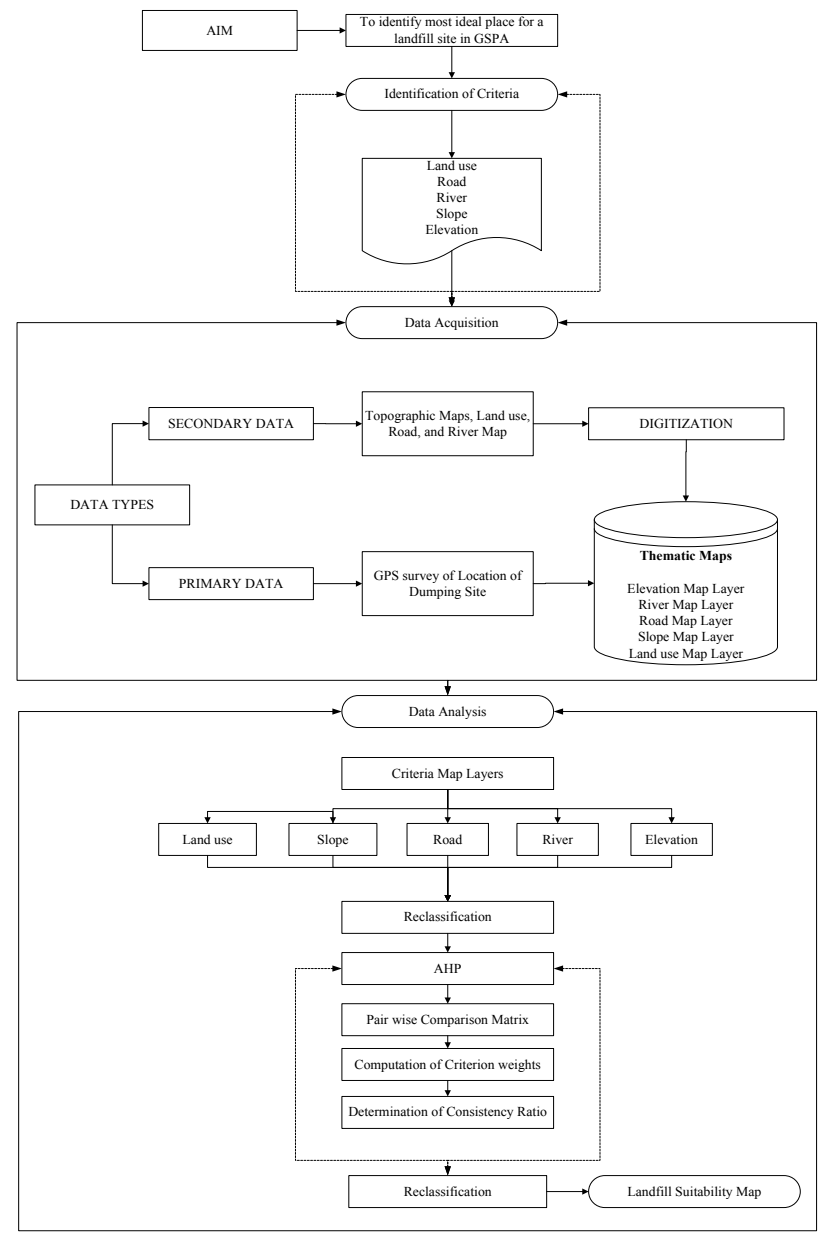

Figure 3.1. Methodology of the study

\section{ANALYSIS}

\subsection{Criterion for Landfill Siting}

Siting a sanitary landfill requires an extensive evaluation process in order to identify the optimum available disposal location. This location must comply with the requirements of the existing governmental regulations and at the same time must minimize economic, environmental, health, and social costs (Siddiqui et al., 1996). These factors may be presented in many ways; however, the most useful way is the one that may be easily understood by the community (Tchobanoglous et al., 1993).

In this study, the guidelines of GSPA are considered for landfill site identification. The selections of disposal sites were carried out through a multi-level screening process. Subsequently, a GIS-based constraint mapping was employed to eliminate the environmentally unsuitable sites and to narrow down the number of sites for further consideration. The list of factors considered for selecting the disposal sites are indicated as- Land cover, Road, Slope, River and Elevation.

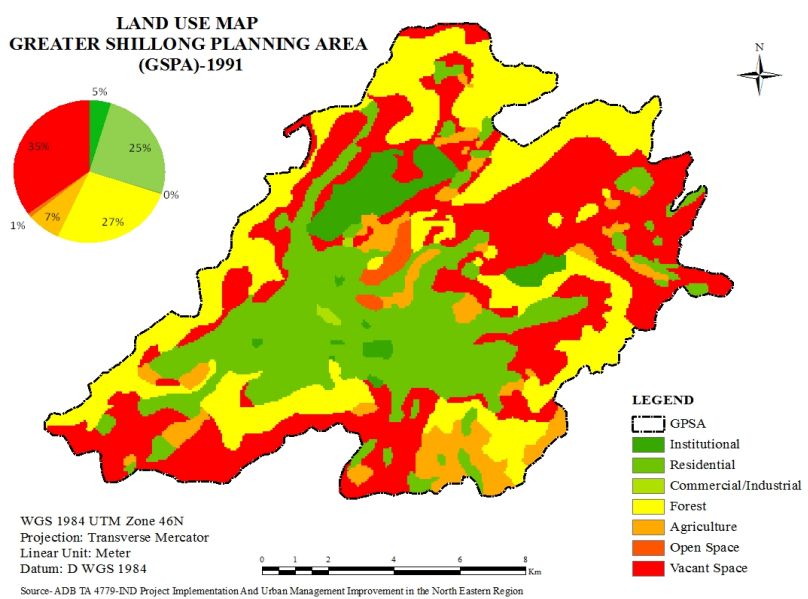

Figure 4.1. Land Use map of the GSPA

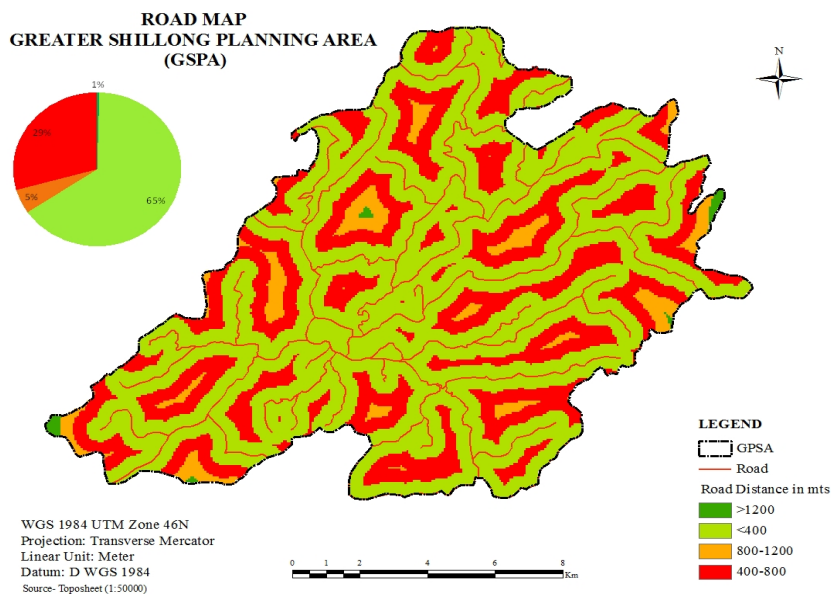

Figure 4.2 Major Road network and buffer of the GSPA 


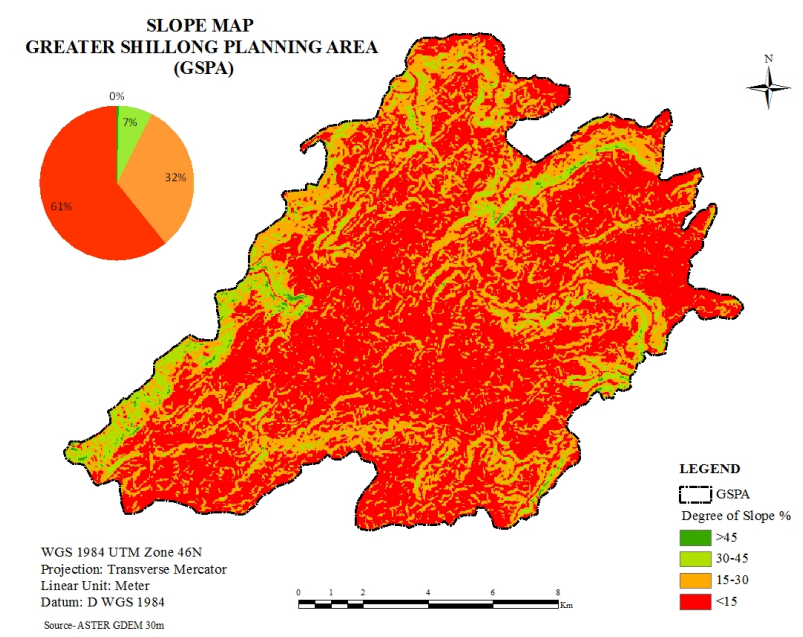

Figure 4.3. Slope map of the GSPA

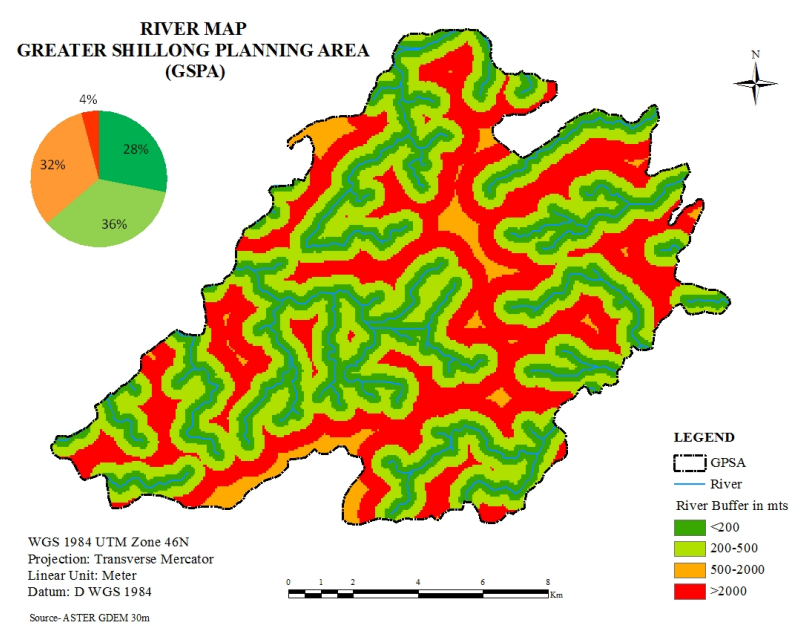

Figure 4.4. Major River network and buffer of the GSPA

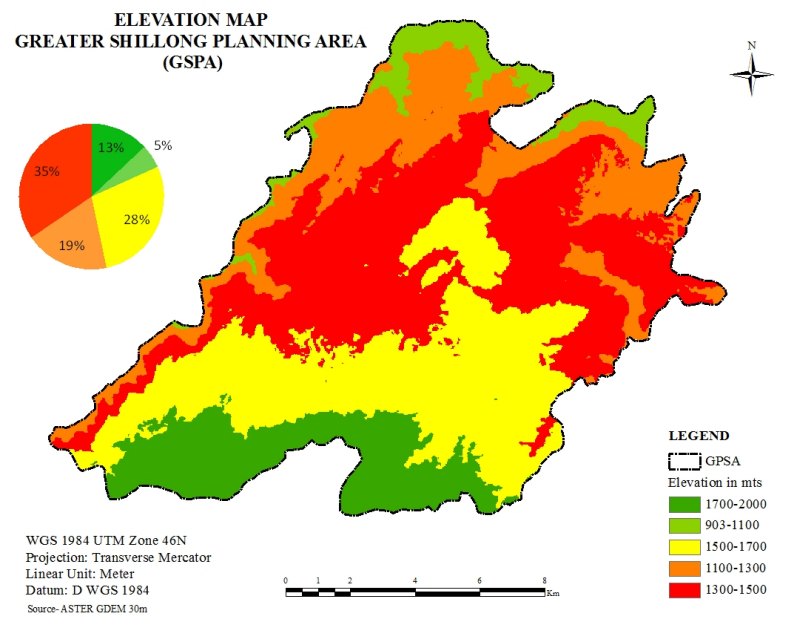

Figure 4.5. Elevation map of the GSPA

4.2 Multi-Criteria Decision Analysis (MCDA)
Using MCDA the best suitable location is identified with fulfilling the criteria i.e. the area should be $>5$ acres, located $400 \mathrm{~m}$ away from the road and the landfill area must be located away from the residential areas. Therefore location "A" has high probability of setting up land landfill, location "B" would get the second probability and location " $\mathrm{C}$ " would get the third preferences. (Figure 8)

\subsection{Computation of site suitability Index}

All five criteria maps were converted into raster format, so that for each pixel, a score can be determined (Jain and Subbaiah, 2007). All the criteria maps were integrated and overlaid and final site suitability map (Map 4.8) was prepared by the following formula:

$$
\text { Suitability Map }=\sum[\text { Criteria map * weight }]
$$

Suitability index $=\left([\text { Elevation }]^{*} 0.035\right)+\left([\text { River }]^{*} 0.068\right)+$

$([$ Road $] * 0.143)+([$ Slope $] * 0.242)+([$ Land use $] * 0.512)$

Table 4.12: Area under different suitability categories

\begin{tabular}{|l|r|r|}
\hline \multicolumn{1}{|c|}{ Suitability class } & Area (Sq. Km) & \multicolumn{1}{c|}{ Area in \% } \\
\hline Very Low Suitability & 31.551 & 18.586 \\
\hline Low Suitability & 23.592 & 13.897 \\
\hline Moderately Suitable & 47.774 & 28.142 \\
\hline High Suitability & 23.257 & 13.699 \\
\hline Highest Suitability & 43.586 & 25.675 \\
\hline
\end{tabular}

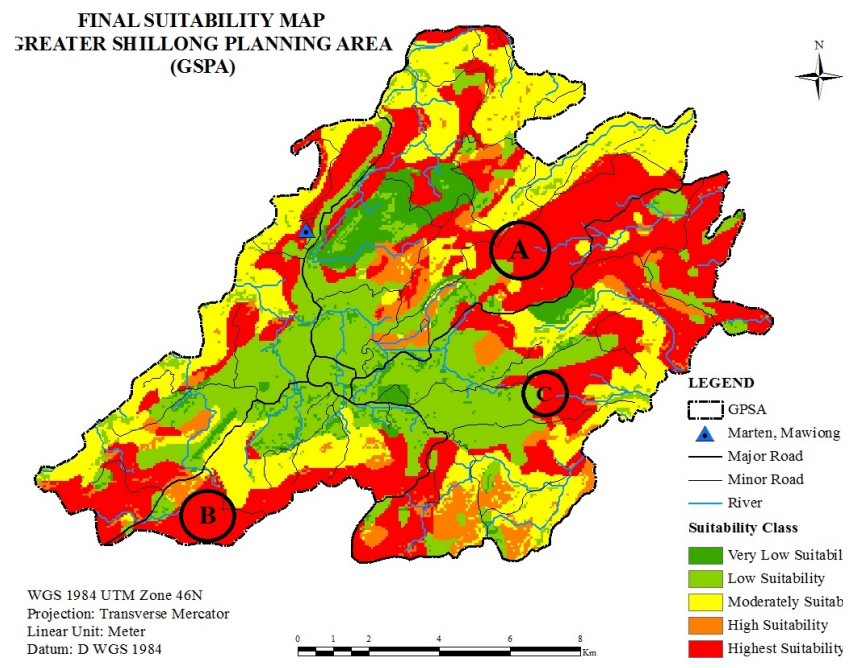

Figure 4.6. Site-suitability map of Landfill the proposed site
(A) $1^{\text {st }}$ Preference
(B) $2^{\text {nd }}$ Preference
(C) $3^{\text {rd }}$ Preference

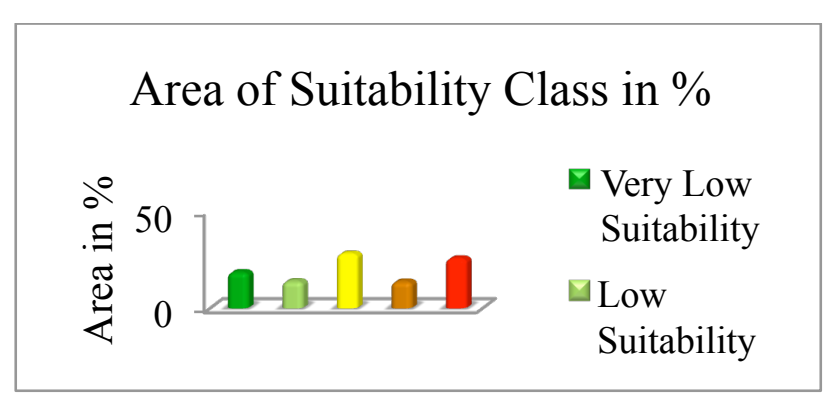

Figure 4.7. Area of different classes of suitability 


\section{FINDINGS}

The Waste Disposal Management practised in GSPA is highly inadequate. The garbage that was to be disposed in suitable dumping bins are not carried out and the garbage that was to be collected from the dumping bins and final disposed to the landfill is not regular. In the SMB area $45.91 \%$ (78.42 MT) of the waste generated is collected while outside the SMB area is only $32.61 \%$ (45.99 MT) and for the entire GSPA the percentage of garbage collected are about $41 \%$.

Due to population growth in GSPA the amount of garbage is increasing. The only dumping ground of the GSPA i.e. Marten, Mawiong, capacity of holding garbage is decreasing. The sanitary landfill site is 5.0 acres, not large enough to meet the Municipal Solid Wastes (Management and Handling) rules, 2000 (schedule II), requirements to contain up to 20-25 years. Therefore alternative search of new landfill site is essential.

With the help of this analysis suitable area of landfill is being identified. The total area coverage of $170.690 \mathrm{sq}$. $\mathrm{km}, 25.670 \%$ is found to be more suitable and $18.586 \%$ is unsuitable area in setting up a landfill. An area, which is situated in eastern part of GSPA, is most suitable that fulfils all criterion required for setting up a landfill.

Most important component in decision-making is that it should fulfil all required criterion as considered. AHP helps us in finding the best suitable site with true judgement. In this study the selected criterion are Land cover (Vacant space), Slope $\left(<15^{\circ}\right)$, Road Proximity (400$800 \mathrm{~m})$, Distance from River $(>2000 \mathrm{~m})$ and Elevation $(1300-1500 \mathrm{~m})$. The new area for landfill setup should be more than 5.0 acres.

The existing location of landfill, which is $8 \mathrm{~km}$ away from the city centre, where collected wastes from the city are disposed. The site has been operational since 1938 . Umiam Lake is approximately $3.0 \mathrm{~km}$ away from the disposal site. Umiam Lake is a "Potential Ramsar site". It is not officially a Ramsar designated wetland; however the site design and environmental mitigation measures needs to avoid degradation of water quality of the surrounding area.

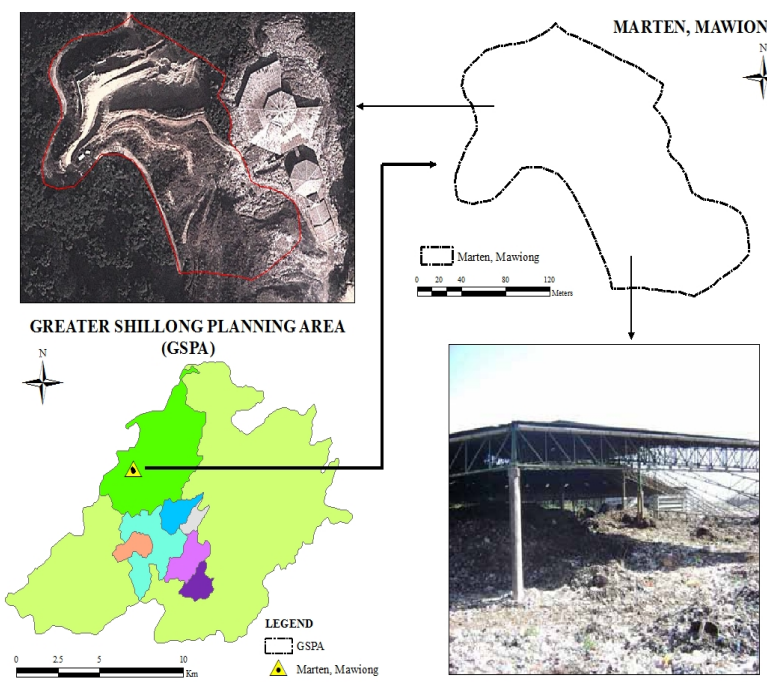

Figure 5.1. Elevation map of the GSPA

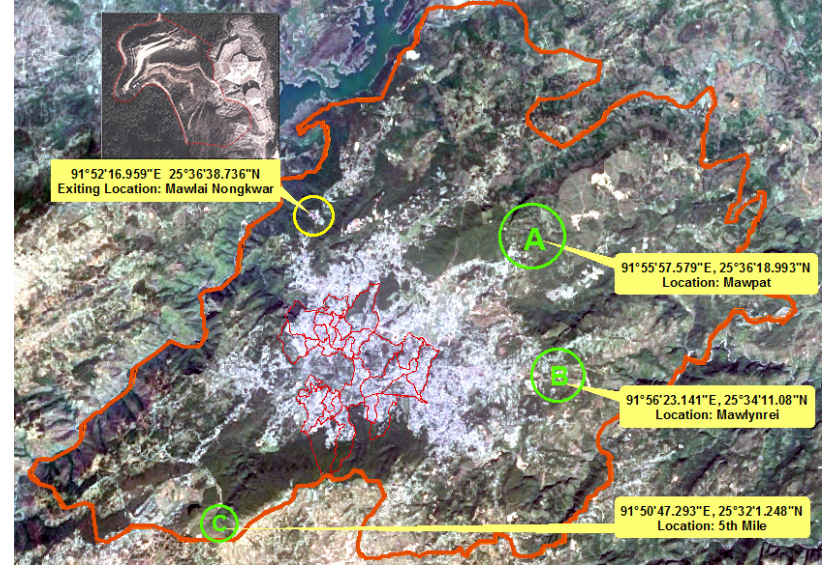

Figure 5.2. Proposed locations for new waste dumping site

\section{CONCLUSION}

The existing landfill for waste disposal site located in Marten of Shillong is not adequate to collect the increasing amount of garbage generated by the growing population of Greater Shillong Planning Area. Planners and decision makers are in look for a new landfill sites to manage the additional waste generated in the city. Using modern tools in preparing site suitably map will provide accurate information about the existing land use/landcover, surrounding environment, location of road, river, slope etc. to identify a suitable site. The ideal area identified using MCDA is located in three preference locations. They are mapped in A, B, C as preference wise, which are in eastern part of the GSPA.

The use of RS and GIS provides accurate and authentic results, it may have been difficult manually; this technique helps us in minimising the hurdles. Remote Sensing helps us in easy and quick access to the data required and GIS helps in processing the data and finding the best result in quick time. Today Remote Sensing and GIS application play an important role in solving problems of all kinds with accurate results for any study.

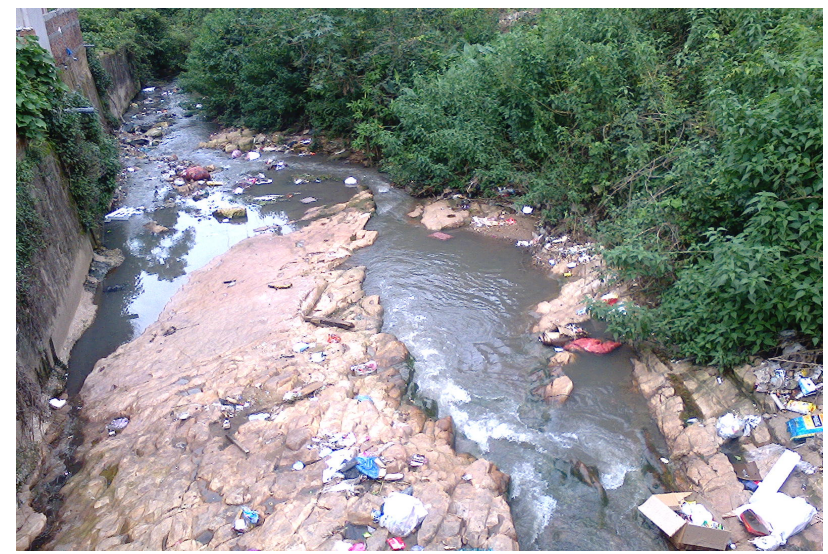

Plate 6.1. Waste dumped on the riverbed 


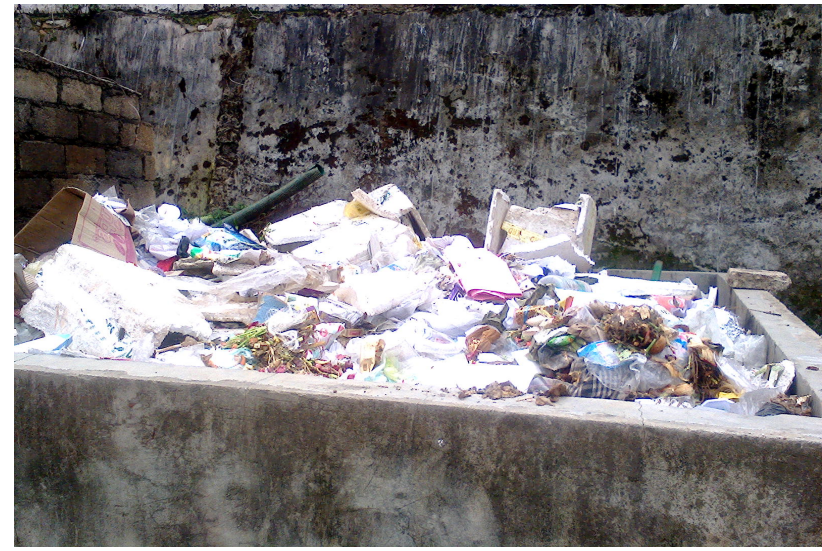

Plate 6.2. Garbage disposal bin

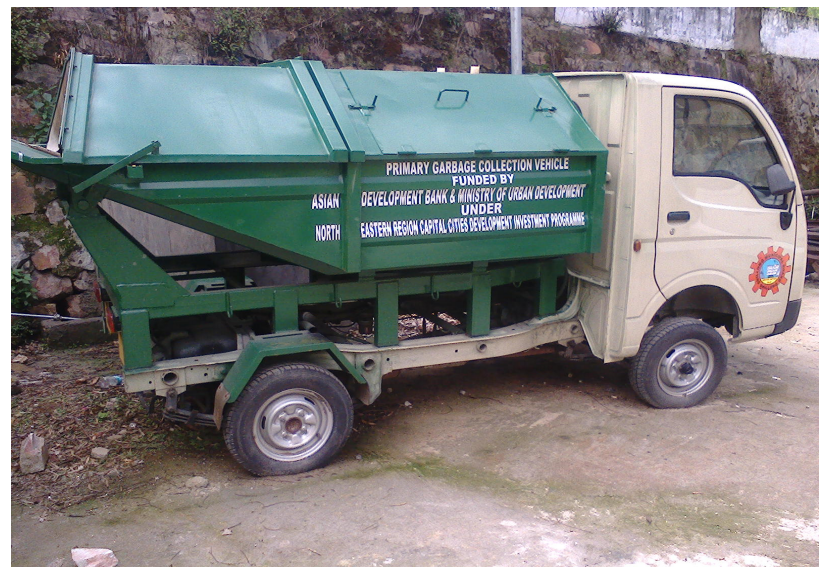

Plate 6.3. Garbage collection vehicle

\section{REFERENCES}

Akinci, H., Ozalp, A. Y., et al., 2013. Agricultural land use suitability analysis using GIS and AHP technique, Computers and Electronics in Agriculture, Vol. 97, pp. 71-82.

Alshuwaikhat, H. M., \& Nasef K., 1996. A GIS-based Spatial Decision Support System for Suitability Assessment and land Use Allocation, The Arabian Journal for Science, Vol. 21, Number 4A, pp. 525 - 543, KFUPM, KSA.

Chandio, I.A., Matori, A.N., et al., 2011. GIS- based Land Suitability Analysis Using AHP for Public Parks Planning in Larkana City, Modern Applied Science, Vol. 5, No. 4.

Das, P. T., \& Sudhakar, S., 2014. Land Suitability Analysis for Orange \& Pineapple: A Multi-Criteria Decision Making Approach Using Geo Spatial Technology, Journal of Geographic Information System, Vol. 6, pp. 40-44.

Elmira, S., Behzad, N., Mazlin, B. M., Ibrahim, K., Halima, T., Saadiah, H., 2010. Urban solid waste management based on Geo-informatics technology, University Putra Malaysia, Malaysia, Environmental Engineering and Management Program School of Environment, Resources and Development SERD.

Jain, K., \& Subbaiah Y.V., 2007. Site Suitability Analysis for Urban Development using GIS, Roorkee, Journal of Applied Sciences, Vol. 7(18), pp. 2576-2583.
Kumar, M., \& Shaikh, V. R., 2013. Site Suitability Analysis for Urban Development Using GIS Based Multi-criteria Evaluation Technique, Indian Society Of Remote Sensing, Vol. 41(2), pp. 417-42.

Malczewski, J., 1999. GIS and Multicriteria Decision Analysis. John Wiley \& Sons, Canada, pp. 392.

Mendas, A., \& Delali A., 2012. Integration of Multi Criteria Decision Analysis in GIS to develop land suitability for agriculture: Application to durum wheat cultivation in the region of Mleta in Algeria, Computers and Electronics in Agriculture, Vol. 83, pp. 117-126.

Nishanth. T., Prakash M. N., \& Vijith. H., 2010. Suitable site determination for urban solid waste disposal using GIS and Remote sensing techniques in Kottayam Municipality, India, International Journal of Geomatics and Geosciences, Vol. 1(2), pp. 197-210.

Pareta, K., 2013. Remote Sensing and GIS Based Site Suitability Analysis for Tourism Development, International Journal of Advanced Research in Engineering and Applied Sciences, Vol. 2(5), pp. 43-58.

Paul, S., 2012. Location allocation for urban waste disposal site using multi-criteria analysis: A study on Nabadwip Municipality, West Bengal, India, International Journal of Geomatics and Geosciences, Vol. 3(1), pp. 74-88.

Samah, M. A. A., \& Manaf, L. A., et al., 2011. Solid Waste Management: Analytical Hierarchy Process (AHP) Application of Selecting Treatment Technology in Sepang Municipal Council, Malaysia, Current World Environment, Vol. 6(1), pp. $1-16$.

Sener, S., Sener, E., Nas, B., 2011. Selection of landfill site using GIS and multicriteria decision analysis for Beysehir Lake Catchment Area Konya, Turkey, J. Eng. Sci., Vol. 1(3), pp. 134-144.

Singh, Y., Chauhan, M. S., \& Katiyar, S. K., 2012. SWM of Kolar Municipality Using Remote Sensing and GIS Techniques, International Journal of Advance Technology \& Engineering Research (IJATER), Vol. 2(1), pp. 30-33.

Yadav, S. K., 2013. GIS Based Approach for Site Selection in Waste Management, International Journal of Environmental Engineering and Management, ISSN 2231-1319, Vol. 4(5), pp. 507-514

Revised: March 2015 